\title{
INCREASED PRODUCTION OF AMINOGLYCOSIDES ASSOCIATED WITH AMPLIFIED ANTIBIOTIC RESISTANCE GENES
}

\author{
R. Crameri and J. E. Davies \\ Biogen S.A. \\ P.O. Box 1211 Geneva, Switzerland
}

(Received for publication July 26, 1985)

\begin{abstract}
The $6^{\prime}-N$-acetyltransferase derived from Streptomyces kanamyceticus strain M1164 was cloned on to the high copy plasmid vector pIJ702 and introduced into S. kanamyceticus (ATCC 12853, a kanamycin producer) and $S$. fradiae (ATCC 10745, a neomycin producer). In both cases transformants containing the recombinant plasmid showed increased resistance to a number of aminoglycoside antibiotics and substantially increased production of kanamycin and neomycin. This demonstrates that specific amplification of gene products associated with antibiotic biosynthesis provides a means for improving antibiotic production.
\end{abstract}

Aminoglycoside/aminocyclitol antibiotics constitute a large group of chemically related antibiotics containing aminosugar residues ${ }^{1}$. They are produced by a variety of different bacterial genera such are Streptomyces, Micromonospora, Bacillus and Pseudomonas. In spite of their toxicity ${ }^{2)}$ they remain one of the most potent group of chemotherapeutic agents against serious Gram-positive and Gramnegative bacterial infections. Natural fermentation products (kanamycins, neomycins, gentamicins and tobramycin), as well as semisynthetic derivatives (amikacin, dibekacin and netilmicin) are used ${ }^{3)}$. The antimicrobial activity of these drugs results from an interaction with the ribosomes of sensitive microorganisms leading to inhibition of protein synthesis ${ }^{4)}$. The extensive clinical use of aminoglycoside antibiotics has led to the selection of organisms resistant to their inhibitory action. The primary mechanism of resistance in clinical situations is the inheritance of plasmids encoding aminoglycoside detoxification mechanisms ( $O$-phosphorylation, $\mathrm{N}$-acetylation and $\mathrm{O}$-adenylylation). The newer, semisynthetic aminoglycosides have been designed to be less susceptible to enzymatic modification; to some extent this approach has been successful.

Similar mechanisms of resistance have been characterised in aminoglycoside-producing microorganisms and it has been suggested that antibiotic-producing organisms may have provided the source from which resistance mechanisms in clinical isolates could have evolved ${ }^{5)}$. The precise role of the aminoglycoside modifying enzymes in aminoglycoside production remains obscure. It is quite possible that they provide a mechanisms by which the producing organisms avoid autotoxicity during antibiotic biosynthesis. On the other hand some studies have suggested that the aminoglycoside modifying enzymes are actually involved in the pathways of biosynthesis. Biologically inactive $N$ acetyl derivatives of neomycin ${ }^{6)}$, kanamycin $\mathrm{B}^{7)}$, and ribostamycin ${ }^{8)}$ have been isolated from fermentation broths of producing strains. In addition, it has been known for some time that aminoglycoside producing organisms possess both inactivating enzymes and enyzmes able to restore biologically active antibiotics from the inactivated forms. For example the presence of streptomycin 6-phosphotransferases ${ }^{9)}$ and streptomycin-phosphate phosphohydrolase ${ }^{10,11)}$ in streptomycin-producing strains and the presence of both kanamycin $6^{\prime}-N$-acetyltransferase and acetylkanamycin iminohydrolase in 
the kanamycin producer $S$. kanamyceticus $^{12)}$. High level aminoglycoside resistant strains are often overproducers $^{13)}$ and in some cases increased levels of aminoglycoside production correlate with increased levels of aminoglycoside modifying enzymes ${ }^{14)}$; moreover loss of production frequently correlates with the loss of the modifying activities ${ }^{14 \sim 17}$.

In order to establish the nature of the relationship between aminoglycoside production and resistance we have used Streptomyces cloning systems ${ }^{18,10)}$ to test directly the effects of changed aminoglycoside modifying enzyme content on antibiotic resistance and productivity in producing strains.

In this report we describe the effects of a cloned aminoglycoside $6^{\prime}-N$-acetyltransferase on antibiotic yields, antibiotic resistance and modification activities in two aminoglycoside producing strains.

\section{Materials and Methods}

\section{Bacterial Strains and Plasmids}

S. lividans strain 6620), S. kanamyceticus strain ATCC 12853 and S. fradiae strain ATCC 10745 were used as hosts in transformation. Staphylococcus aureus strain 209P (ATCC 6538P) was used for detection of both antibiotic production and presence of aminoglycoside modifying enzymes ${ }^{17)}$. Plasmid pMS18 ${ }^{21}$ ) was used as source of a $6^{\prime}-N$-acetyltransferase (AAC6') gene derived from the chromosome of S. kanamyceticus strain M1164. As cloning vectors pIJ70222) and the low copy number plasmid pR2, a derivative of pIJ61 ${ }^{23)}$ carrying a deletion extending into the aminoglycoside $3^{\prime}-O$ phosphotransferase (APH 3') gene (unpublished result), were used.

\section{Media, Strain Storage and Culture Conditions}

Stock cultures of Streptomyces strains were grown and maintained on solid agar media ${ }^{24)}$. Stock suspensions of spores were stored on $50 \%$ sterile glycerol at $-20^{\circ} \mathrm{C}$. For protoplast preparation, strains were grown on YEMEG medium ${ }^{25)}$ containing sucrose $(34 \%), \mathrm{MgCl}_{2}(5 \mathrm{~mm})$ and glycine $(0.6 \%)$. For regeneration transformed protoplasts were plated on a osmotically stabilized medium as described by HiNTERMANN et al. ${ }^{28)}$. For antibiotic production and aminoglycoside modifying enzyme determinations strains were grown on 1,000-ml Erlenmeyer flasks with 4 baffles containing $100 \mathrm{ml}$ medium at $30^{\circ} \mathrm{C}$ on a rotary shaker $(220 \mathrm{rpm}) ; S$. fradiae on Tryptic soya broth CM-129 (Oxoid), S. kanamyceticus on a minimal medium according to BASAK and MAJUMDAR ${ }^{27)}$. Minimal inhibitory concentrations (MIC) were determined according to ONO et al. ${ }^{17}$ ) on yeast extract - malt extract agar containing antibiotics at various concentrations. Staphylococcus aureus was grown overnight at $37^{\circ} \mathrm{C}$ on a rotary shaker in Tryptic soya broth CM-129. After centrifugation (5 minutes, 10,000 rpm) and washing with sterile deionized water, cells were stored in a $50 \%$ glycerol suspension at $-70^{\circ} \mathrm{C}$.

\section{Protoplast Preparations, Transformations and Selection for Transformants}

Streptomyces protoplasts were prepared and transformed according to THOMPSON et al. ${ }^{23)}$. Transformants were selected by the overlay method ${ }^{28)}$ using thiostrepton $(500 \mu \mathrm{g} / \mathrm{ml}, 2.5 \mathrm{ml}$ soft agar/ plate) and inserts were detected by insertional inactivation of the melanin gene ${ }^{22)}$ or directly selecting for aminoglycoside resistance using amikacin $(500 \mu \mathrm{g} / \mathrm{ml}, 2.5 \mathrm{ml}$ soft agar/plate).

\section{Plasmid Preparations and DNA Manipulations}

For mini-lysates as well as for large scale preparations plasmids were isolated and purified according to $\mathrm{KIESER}^{29)}$; restriction analyses and ligations were performed according to THOMPSON et al. ${ }^{23)}$. Restriction enzymes and T4 DNA ligase were of commercial source (BRL) and used according to the suppliers recommendations. Agarose gel electrophoresis was carried out according to MANIATIS et al. ${ }^{30)}$ using Tris-acetate or Tris-borate buffer.

\section{Preparation for Cell-free Extracts}

Cell-free extracts were prepared according to Benveniste and DAviES ${ }^{5)}$ and stored at $-70^{\circ} \mathrm{C}$ until used. 
Determination of Neomycin and Kanamycin Production

During the course of fermentation $2 \mathrm{ml}$ samples were removed, centrifuged (10 minutes, 10,000 $\mathrm{rpm}$ at $4^{\circ} \mathrm{C}$ ) and the supernatants stored at $-20^{\circ} \mathrm{C}$. The estimation of kanamycin and neomycin production $(\mu \mathrm{g} / \mathrm{ml})$ was according to ONO et al. ${ }^{17)}$ by measuring the inhibition zones against $S$. aureus strain 209P. Commercial kanamycin and neomycin sulfate (Sigma) were used as standards to quantify the amounts of antibiotic produced.

Determination of Aminoglycoside Modifying Activities

Extracts of wild type strains and of transformants were tested for their ability to transfer $\left[{ }^{14} \mathrm{C}\right]-$ acetyl groups from $\left[{ }^{14} \mathrm{C}\right]$ acetyl-coenzyme $\mathrm{A}$ to kanamycin as previously described ${ }^{5)}$. Acetylated antibiotic was then separated from unreacted cofactor by absorption onto phosphocellulose paper as described by HAAS and DowDING ${ }^{31)}$. Reaction mixtures contained $25 \mu \mathrm{M}$ kanamycin, cell free-extract to $20 \mu$ g total protein, $3 \mu \mathrm{l}$ of $\left[1-{ }^{14} \mathrm{C}\right]$ acetyl-coenzyme $\mathrm{A}(20 \mu \mathrm{Ci} / \mathrm{ml}, 59.3 \mathrm{mCi} / \mathrm{mmol})$ and buffer $(10 \mathrm{~mm}$ Tris- $\mathrm{HCl}$ ( $\mathrm{pH}$ 7.6), $10 \mathrm{~mm} \mathrm{MgCl}_{2}, 50 \mathrm{mM} \mathrm{NH}_{4} \mathrm{Cl}, 3 \mathrm{~mm}$ 2-mercaptoethanol) to a total volume of $40 \mu \mathrm{l}$. Incubation was continued for 60 minutes at $30^{\circ} \mathrm{C}$. Enzymatic activities were expressed as arbitary units i.e. cpm incorporated into kanamycin per $1 \mu \mathrm{g}$ total protein per hour $\times 10^{-3}$. Controls contained all components except cell-free extracts.

\section{Results}

Subcloning of the AAC6'-gene from pMS18 onto pIJ702 and pR2

pMS18, a plasmid containing a $1.9 \mathrm{~kb}$ fragment encoding an aminoglycoside $6^{\prime}$-acetyltransferase derived from Streptomycetes kanamyceticus strain M1164 ${ }^{20)}$ was digested with restriction endonuclease $B c l \mathrm{I}$ and ligated with pIJ702 previously cut with $B g l \mathrm{II}$ or pR2 cut with $B c l$-I; ligation mixtures were transformed into $S$. lividans protoplasts. Transformants were selected as colonies able to grow in the presence of thiostrepton $(50 \mu \mathrm{g} / \mathrm{ml})$ and kanamycin $(50 \mu \mathrm{g} / \mathrm{ml})$. The presence of the $1.9 \mathrm{~kb}$ fragment coding for the AAC6' was detected by agarose gel electrophoresis after restriction with $B c l$ I (not shown) and in vivo expression was demonstrated by growth of the transformants on media containing a variety of aminoglycoside antibiotics (Table 1). As shown in this table, transformants containing the high copy number construction (pIJ702:: AAC6') are more resistant against aminoglycosides than transformants containing the low copy number construction (pR2:: AAC6').

Transformation of the pIJ702 Hybrid Construction into Production

Strains and Effects on the Resistance Patterns

The chimeric plasmid pIJ702:: AAC6' isolated from S. lividans was used to transform S. kanamyceticus and $S$. fradiae protoplats. Transformants were isolated as colonies able to grow in the

Table 1. Effects of a cloned AAC6' on the resistance levels of S. lividans 66 against different aminoglycoside antibiotics $(\mu \mathrm{g} / \mathrm{ml})$.

\begin{tabular}{lrrrrrrr}
\hline \multicolumn{1}{c}{ Plasmid } & KMA $^{*}$ & AMI & RMS & BUT & NEO & PAR $^{+}$ & LVDM $^{+}$ \\
\hline None & 2 & $<1$ & 10 & $<5$ & $<1$ & 10 & 20 \\
pIJ702 & 2 & $<1$ & 10 & $<5$ & $<1$ & 10 & 20 \\
pR2 & 2 & $<1$ & 10 & $<5$ & $<1$ & 10 & 20 \\
pIJ702:: AAC6 & 360 & $>200$ & $>400$ & $>200$ & 10 & 10 & 20 \\
pR2:: AAC6 & 230 & 80 & $>400$ & $>200$ & 5 & 10 & 20 \\
\hline
\end{tabular}

+ 6' substitution R-OH: No modification site for AAC6'.

* Abbreviations: KMA; Kanamycin A, AMI; amikacin, RMS; ribostamycin, BUT; butirosin, NEO; neomycin, PAR; paromomycin, LVDM; lividomycin, AAC6 $6^{\prime}$; aminoglycoside $6^{\prime}$ - $N$-acetyltransferase. pIJ 702:: AAC6' and pR2:: AAC6'; Chimeric plasmids containing the cloned AAC6' gene. 
Table 2. Effects of a cloned AAC6' acetyltransferase on the resistance levels of S. kanamyceticus ATCC 12853 against different aminoglycoside antibiotics $(\mu \mathrm{g} / \mathrm{ml})$.

\begin{tabular}{lcccccc}
\hline Plasmid & KMA $^{2}$ & AMI & RMS & BUT & PAR $^{+}$ & LVDM $^{+}$ \\
\hline None & 140 & 25 & $>200$ & 100 & 10 & 25 \\
pIJ702:: AAC6' & 750 & 260 & $>200$ & 100 & 10 & 25 \\
$*$ & 550 & 180 & $>200$ & 100 & 10 & 25 \\
\hline
\end{tabular}

* This single transformant shows an intermediate resistance.

+ 6' substitution R-OH: No modification site for AAC6'.

a See the footnotes in Table 1.

Table 3. Effects of a cloned AAC6' acetyltransferase on the resistance levels of S. fradiae ATCC 10745 against different aminoglycoside antibiotics $(\mu \mathrm{g} / \mathrm{ml})$.

\begin{tabular}{lrrrrrrr}
\hline \multicolumn{1}{c}{ Plasmid } & KMA $^{\mathrm{a}}$ & AMI & RMS & BUT & NEO & PAR & LVDM \\
\hline None & 90 & 30 & $>500$ & 30 & 180 & $>100$ & $>40$ \\
pIJ702 & 90 & 30 & $>500$ & 30 & 180 & $>100$ & $>40$ \\
pIJ702:: AAC6' & $>200$ & $>100$ & $>500$ & $>160$ & 750 & $>100$ & $>40$ \\
\hline
\end{tabular}

a See the footnotes in Table 1.

Fig. 1. Kanamycin production by S. kanamyceticus ATCC 12853.

- Wild type strain, $\triangle$ single transformant containing pIJ702:: AAC6' and showing an intermediate kanamycin resistance, $\mathbf{\Delta}$ kanamycin high resistant transformants containing pIJ702:: AAC6'.

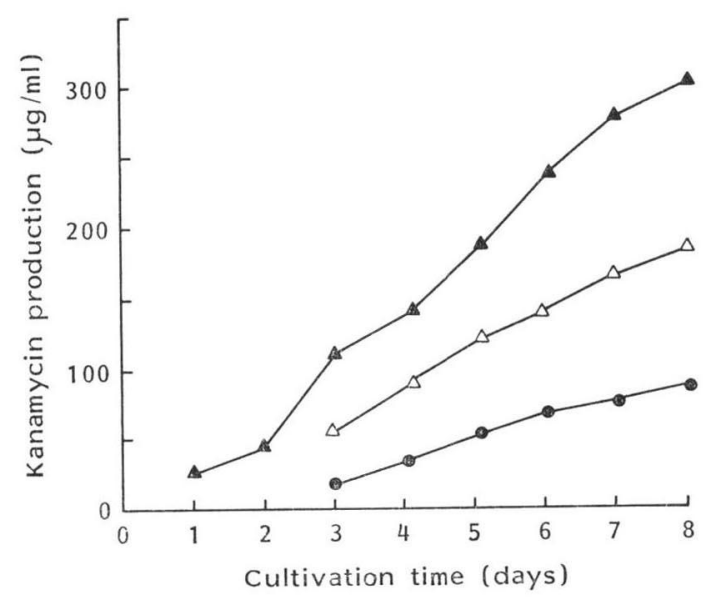

Fig. 2. Neomycin production by $S$. fradiae ATCC 10745.

- Wild type strain, $\bigcirc$ wild type strain containing pIJ702, $\mathbf{\Delta}$ transformants containing pIJ702:: AAC6'.

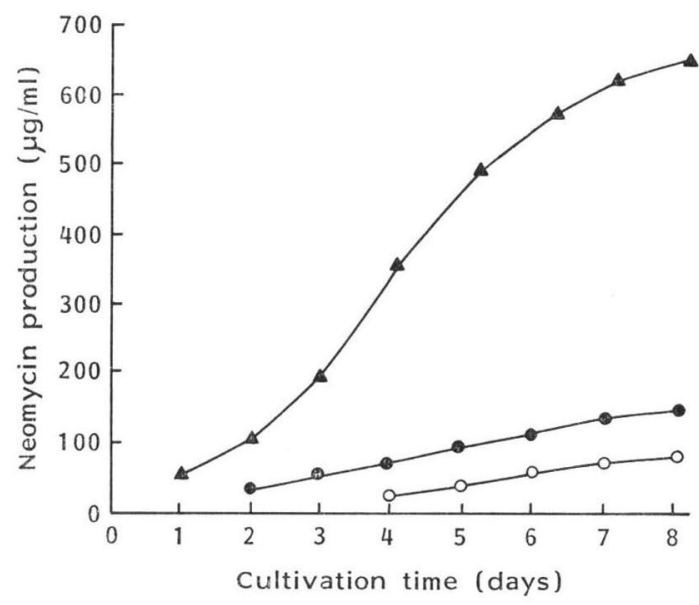

presence of thiostrepton $(50 \mu \mathrm{g} / \mathrm{ml})$ and amikacin $(50 \mu \mathrm{g} / \mathrm{ml})$; the presence of the intact plasmid was confirmed by agarose gel electrophoresis and restriction analysis. The resistance pattern of transformants against aminoglycoside antibiotics was determined. As shown in Tables 2 and 3 the cloned AAC6' markedly increased the levels of resistance against aminoglycoside antibiotics in both $S$. kanamyceticus and S. fradiae.

\section{Influence of Increased Copies of AAC6' on Antibiotic Production}

The wild type strains of $S$. kanamyceticus and $S$. fradiae as well as transformants containing the cloned AAC6' were grown in liquid media and the antibiotic productivity determined. Results are 
summarized in Figs. 1 and 2. To exclude the possibility that high producers were induced by protoplast formation and regeneration, plasmids isolated from $S$. kanamyceticus and $S$. fradiae were retransformed into protoplasts of the respective wild type strain. Five retransformants per strain were tested for production level and resistance pattern. All exhibit production and resistance levels comparable to that of the original transformants (not shown). Note that one transformant of $S$. kanamyceticus showing an intermediate resistance level between wild type and "high" producing trans-

Fig. 3. Acetyltransferase activity in S. fradiae ATCC 10745.

- Protein content, acetyltransferase activity.

(a) Wild type strain.

(b) Transformants containing pIJ702:: AAC6'.

(a)

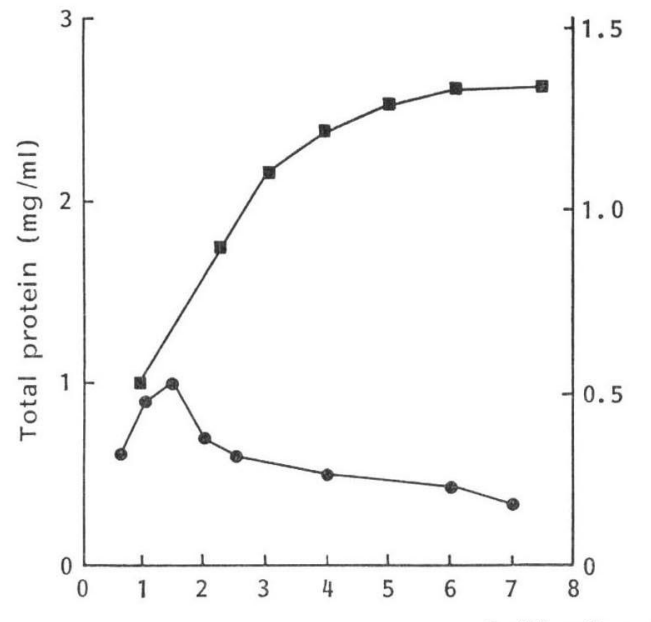

(b)

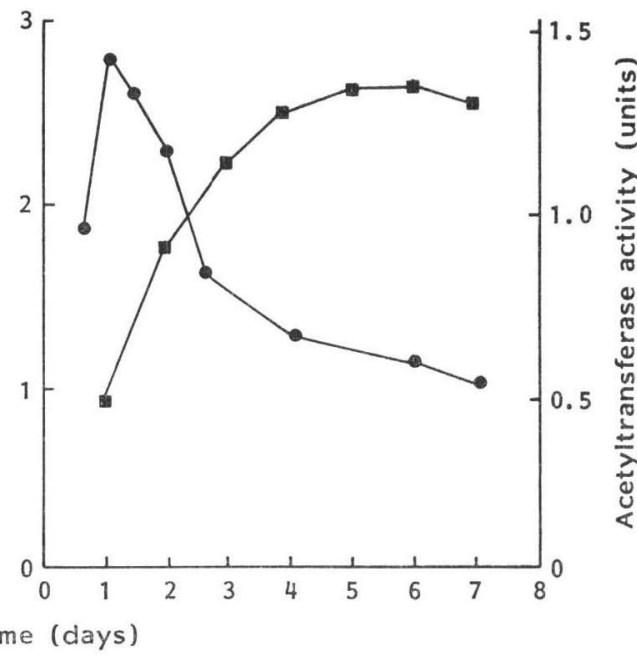

Fig. 4. Acetyltransferase activity in S. kanamyceticus ATCC 12853.

a Protein content, acetyltransferase activity.

(a) Wild type strain.

(b) Transformants containing pIJ702:: AAC6'.

(a)

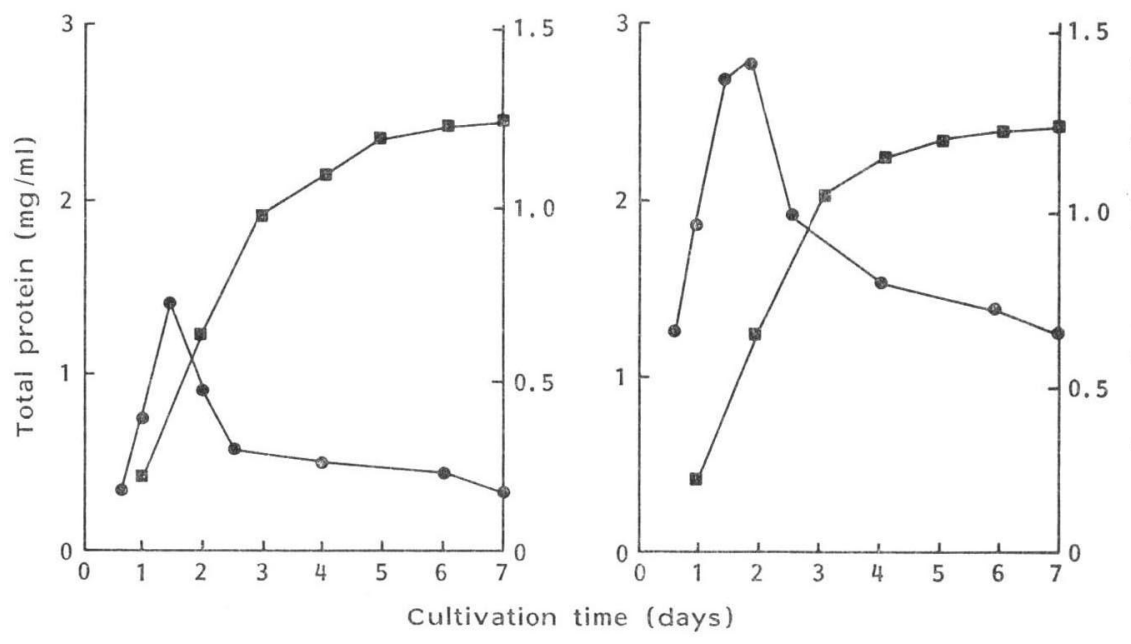

(b) 
formants (Table 2) also shows an intermediate level of kanamycin production (Fig. 1). No differences on the restriction pattern of the plasmids could be detected (not shown).

\section{Acetyltransferase Activities}

Acetyltransferase activity during the fermentation was determined for cell-free extracts of wild type strains as well as for transformants. Results reported in Figs. 3a (S. fradiae) and 4a (S. kanamyceticus) represent the mean of two fermentations runs per strain. Figs. $3 \mathrm{~b}$ and $4 \mathrm{~b}$ represents results obtained fermenting three single transformants of $S$. fradiae and $S$. kanamyceticus respectively. It can be seen that acetyltransferase activity, in presence or absence of plasmid, increased rapidly during the early logarithmic phase of growth and then decreased somewhat during later growth phases.

\section{Discussion}

Cloned modifying enzymes introduced into a "clean" genetic background confer resistance to the host organism. Many aminoglycoside modifying enzymes have been cloned and expressed in Streptomyces lividans. For example both aminoglycoside modifying enzymes present in the neomycin producing streptomycete $S$. fradiae, an $\mathrm{APH}^{\prime}$ ' and a 3 - $\mathrm{N}$-acetyltransferase (AAC3) ${ }^{25)}$. Not surprising was the fact that, in a "shot gun" cloning experiment, some clones contained APH3" modifying activity, others AAC3 activity. Both genes confer low level of resistance to neomycin to their hos $\mathrm{t}^{25)}$; despite of the fact that S. lividans strains containing the cloned $\mathrm{APH}^{\prime}$ gene produced more than $10 \%$ of total protein in form of active aminoglycoside $3^{\prime}$-phosphotransferase ${ }^{32}$. More surprising was the fact that $S$. lividans strains containing both modifying enzymes had aminoglycoside resistance levels comparable to those of the original $\operatorname{strain}^{25)}$. This indicates that cloning of antibiotic resistance genes into a sensitive genetic background is a convenient way to "purify" discrete genes but not necessarily the way to understand the function of such genes in producing strains.

We have shown that a cloned aminoglycoside modifying enzyme can be used to increase both aminoglycoside resistance and antibiotic yields in the producing strains S. fradiae ATCC 10745 and $S$. kanamyceticus ATCC 12853 . We cannot completely exclude the possibility that other genes involved in antibiotic biosynthesis could be encoded by the $1.9 \mathrm{~kb}$ DNA fragment used and consequently be directly involved in yield improvement. Moreover these results do not answer basic questions about roles of aminoglycoside modifying enzymes in aminoglycoside production. The case of $S$. kanamyceticus is somewhat complex since it produces an aminoglycoside acetyltransferase (AAC6 ${ }^{\prime}$ ) during the early growth phase which then decreases rapidly during the logarithmic growth phase of the organism $^{12)}$ (present paper). This enzyme completely inactivates kanamycin and partially neomycin in vitro. During the kanamycin production phase occurring at the end of the growth phase ${ }^{12)}$ resistance to kanamycin has been shown to be due to an acquired ribosomal resistance as demonstrated by cloning the ribosomal resistance gene into $S$. lividans ${ }^{33)}$. The acetyltransferase thus seems not to be responsible for resistance during the kanamycin production phase. Obviously, investigations of cloned genes in different genetic backgrounds do not give conclusive answers about the function of modifying enzymes in producing strains. It seems that, in certain cases, aminoglycoside modifying enzymes are not necessary for resistance or for antibiotic production. There are several examples of aminoglycoside producing strains having resistant ribosomes which do not produce any antibiotic modifying enzymes ${ }^{34,35)}$. However from a more practical (industrial) point of view the question concerns primarily the manipulation of genes as a means of increasing the production of antibiotics. As suggested by THOMPSON and DAVIES ${ }^{36)}$ one of the limiting steps in antibiotic production could be the level of resistance against the antibiotic produced. The isolation of higher producing strains by obtaining mutants with increased resistance levels has been used successfully in the past ${ }^{13,14)}$. The development of cloning systems for the genus Streptomyces provides rational possibilities to test discrete (cloned) genes for effects on antibiotic production. This paper has investigated the influence of a gene encoding a simple antibiotic modification on antibiotic resistance and antibiotic productivity. An 
AAC6' acetyltransferase cloned on a high copy number plasmid was introduced into two producing organisms: S. kanamyceticus ATCC 12853 and S. fradiae ATCC 10745. As shown in Tables 2 and 3 transformants containing the chimeric plasmid are markedly more resistant towards aminoglycoside antibiotics than the wild type strains. With respect to antibiotic production, the transformants show an increased level compared to the isogenic parents. We conclude that increased resistance towards an antibiotic can result in a net increase of antibiotic yields. The complete interpretation of this observation must await additional studies since we do not know if the organisms are high producers because they can tolerate more antibiotic or if the result is due to the introduction of additional levels of a limiting enzyme of the biosynthetic pathway. The transformants show higher modifying enzyme levels compared to wild type strains and presumably make more $\mathrm{N}$-acetylated aminoglycoside; another limiting step in production could be the reactivation of inactivated antibiotic.

There are several other implications of this study that warrant further investigation. What if the gene for the modifying enzyme is cloned into a producing organism that does not already possess such an enzyme? Would one produce a modified antibiotic? What if the resistance mechanism occurring as a result of a target site modification (ribosome) was introduced into a producing organism, or if this type of resistance was placed under constitutive rather than inducible (developmental) control? The choice of appropriate resistance mechanism is going to be crucial when hybrid antibiotics with broadened spectrum are to be produced by genetic engineering. In this respect, the use of a resistance mechanism found in clinical isolates might be more appropriate than the "natural" resistance mechanisms of producing organisms. We may yet use undesirable resistant organisms to our advantage!

\section{Acknowledgment}

The authors gratefully acknowledge Dr. C. J. THOMPson for fruitful discussions and critical reading of the manuscript. R.C. gratefully acknowledges a postdoctoral position at Biogen S.A.

\section{References}

1) Rinehart, K. L., Jr. \& T. Suami, Eds.: Aminocyclitol Antibiotics Symposium Series. Vol. 129, Am. Chem. Soc., Washington, D.C., 1980

2) Koeda, T.; K. Umemura \& M. Yokota: Toxicology and pharmacology of aminoglycoside antibiotics. In Aminoglycoside Antibiotics. Eds., H. UmeZawa \& I. R. Hooper, pp. 293 346, Springer-Verlag, Berlin, 1982

3) Price, K. E.: Aminoglycoside antibiotics: Chemical aspects and future trends. In New Trends in Antibiotics: Research and Therapy. Eds., G. G. Grassi \& L. D. SABATH, pp. 59 82, Elsevier/North-Holland Biomed. Press, New York, 1981

4) TANaka, N.: Mechanism of action of aminoglycoside antibiotics. In Aminoglycoside Antibiotics. Eds., H. UMEZAWA \& I. R. Hooper, pp. $221 \sim 259$, Springer-Verlag, Berlin, 1982

5) Benveniste, R. \& J. Davies: Aminoglycoside antibiotic-inactivating enzymes in actinomycetes similar to those present in clinical isolates of antibiotic-resistant bacteria. Proc. Natl. Acad. Sci. USA 70: 2276 2280,1973

6) Rinehart, K. L., Jr.: The Neomycins and Related Antibiotics. Wiley \& Sons, New York, 1961

7) Murase, M.; T. Ito, S. Fukatsu \& H. Umezawa: Studies on kanamycin related compounds produced during fermentation by mutants of Streptomyces kanamyceticus. Isolation and properties. Progr. Antimicrob. Anticancer. Chemother. 2: 1098 1110, 1970

8) Kojima, M.; N. Ezaki, S. Amano, S. Inouye \& T. NiIda: Bioconversion of ribostamycin (SF-733). II. Isolation and structure of 3- $N$-acetylribostamycin, a microbiologically inactive product of ribostamycin produced by Streptomyces ribosidificus. J. Antibiotics 28: 42 47, 1975

9) Miller, A. L. \& J. B. Walker: Enzymatic phosphorylation of streptomycin by extracts of streptomycinproducing strains of Streptomyces. J. Bacteriol. 99: 401 405, 1969

10) Walker, J. B.: Streptomycin-6-P phosphohydrylase. Methods Enzymol. 43: 465 470, 1975

11) Walker, M. S. \& J. B. WalkeR: Streptomycin biosynthesis. Separation and substrate specificities of phosphatases acting on guanidino-deoxy-scyllo-inositol phosphate and streptomycin-(streptidino) phosphate. J. Biol. Chem. 246: 7034 7040, 1971 
12) Satoh, A. S.; H. Ogawa \& Y. Satomura: Effect of sclerin on production of the aminoglycoside antibiotics accompanied by salvage function in Streptomyces. Agric. Biol. Chem. 39: 1593 1598, 1975

13) Demarn, A. L.: How do antibiotic-producing organisms avoid suicide? Annual New York Acad. Sci. 235: $601 \sim 612,1974$

14) Komatsu, K.; J. Leboul, S. Harford \& J. Davies: Studies of plasmids in neomycin-producing Streptomyces fradiae. In Microbiology 1981. Ed., D. Schlessinger, pp. 384 387, Am. Soc. Microb., Washington, D.C., 1981

15) Shaw, P. D. \& J. Piwowarski: Effects of ethidium bromide and acriflavine on streptomycin-production by Streptomyces bikiniensis. J. Antibiotics 30: 404 408, 1977

16) Yagisawa, M.; T-S. R. Huang \& J. Davies: Possible involvement of plasmids in biosynthesis of neomycin. J. Antibiotics 31: 809 813, 1978

17) Ono, H.; R. Crameri, G. Hintermann \& R. Hütter: Hydroxystreptomycin production and resistance in Streptomyces glaucescens. J. Gen. Microbiol. 129: 529 537, 1983

18) Chater, K.F.; D. A. Hopwood, T. Kieser \& C. J. Thompson: Gene cloning in Streptomyces. Curr. Topics Microbiol. Immunol. 97: 69 95, 1982

19) Hopwood, D. A. \& K. F. Chater: Cloning in Streptomyces: Systems and strategies. In Genetic Engineering. Vol. 4. Eds., J. K. Setlow \& A. Hollaender, pp. 119 145, Plenum, New York, 1982

20) Lomovskaya, N. D.; N. M. Mkrtumian, N. L. Gostimskaya \& V. N. Danilenko: Characterization of temperate actinophage C31 isolated from Streptomyces coelicolor A 3(2). J. Virol. 9: 242 252, 1972

21) Murakami, T.; C. Nojiri, H. Toyama, E. Hayashi, K. Katumata, H. Anzai, Y. Matsuhashi, Y. Yamada \& K. NaGaOKa: Cloning of antibiotic-resistance genes in Streptomyces. J. Antibiotics 36: 1305 1311, 1983

22) Katz, E.; C. J. Thompson \& D. A. Hopwood: Cloning and expression of the tyrosinase gene from Streptomyces antibioticus in Streptomyces lividans. J. Gen. Microbiol. 129: 2703 2714, 1983

23) Thompson, C. J.; T. Kieser, J. M. Ward \& D. A. Hopwood: Physical analysis of antibiotic-resistance genes from Streptomyces and their use in vector constructions. Gene 20: 51 62, 1982

24) Crameri, R.; T. Kieser, H. Ono, J. Sanchez \& R. Hütter: Chromosomal instability in Streptomyces glaucescens: Mapping of streptomycin-sensitive mutants. J. Gen. Microbiol. 129: 519 527, 1983

25) Thompson, C. J.; R. H. Skinner, J. Thompson, J. M. Ward, D. A. Hopwood \& E. Cundliffe: Biochemical characterization of resistance determinants cloned from antibiotic-producing streptomycetes. J. Bacteriol. 151: 678 685, 1982

26) Hintermann, G.; R. Crameri, M. Vögtli \& R. Hütter: Streptomycin-sensitivity in Streptomyces glaucescens is due to deletions comprising the structural gene coding for a specific phosphotransferase. Mol. Gen. Genet. 196: 513 520, 1984

27) BASAK, K. \& S. K. MAJUmdAR: Mineral nutrition of Streptomyces kanamyceticus for kanamycin formation. Antimicrob. Agents Chemother. 8: 391 395, 1975

28) Kieser, T.; D. A. Hopwood, H. M. Wright \& C. J. Thompson: pIJ101, a multi-copy broad host-range Streptomyces plasmid: Functional analysis and development of DNA cloning vectors. Mol. Gen. Genet. 185: $223 \sim 238,1982$

29) KIESER, T.: Factors affecting the isolation of cccDNA from Streptomyces lividans and Escherichia coli. Plasmid 12: 19 36, 1984

30) Maniatis, T.; E. F. Fritsch \& J. Sambrook: Molecular Cloning, a Laboratory Manual. Cold Spring Habour Laboratory, New York, 1982

31) HaAs, M. J. \& J. E. Dowding: Aminoglycoside modifying enzymes. Methods Enzymol. Methods Enzymol. 43: 611 628, 1975

32) Thompson, C. J. \& G. S. Gray: Nucleotide sequence of a streptomycete aminoglycoside phosphotransferase gene and its relationship to phosphotransferases encoded by resistance plasmids. Proc. Natl. Acad. Sci. USA 80: 5190 5194, 1983

33) Nakano, M. M.; H. Mashiko \& H. Ogawara: Cloning of the kanamycin resistance gene from a kanamycin-producing Streptomyces species. J. Bacteriol. 157: 79 83, 1984

34) Yамамото, H.; K. Нотta, Y. Okami \& H. Umezawa: Self-resistance of a Streptomyces which produces istamycins. J. Antibiotics 34: 824 829, 1981

35) PiendL, W. \& A. Böck: Ribosomal resistance in the gentamicin producer organism Micromonospora purpurea. Antimicrob. Agents Chemother. 22: 231 236, 1982

36) Thompson, C. J. \& J. E. Davies: Genetic engineering and aminoglycoside antibiotics. Trends Biotechnol. 2: $43 \sim 46,1984$ 